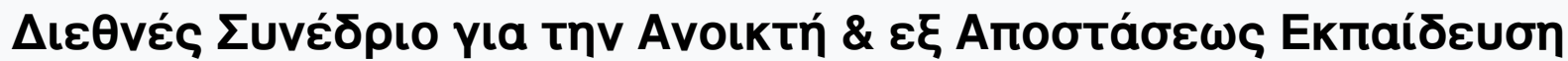

Tó. 5, Ap. 2A (2009)

Open and Distance Education for Global Collaboration \& Educational Development

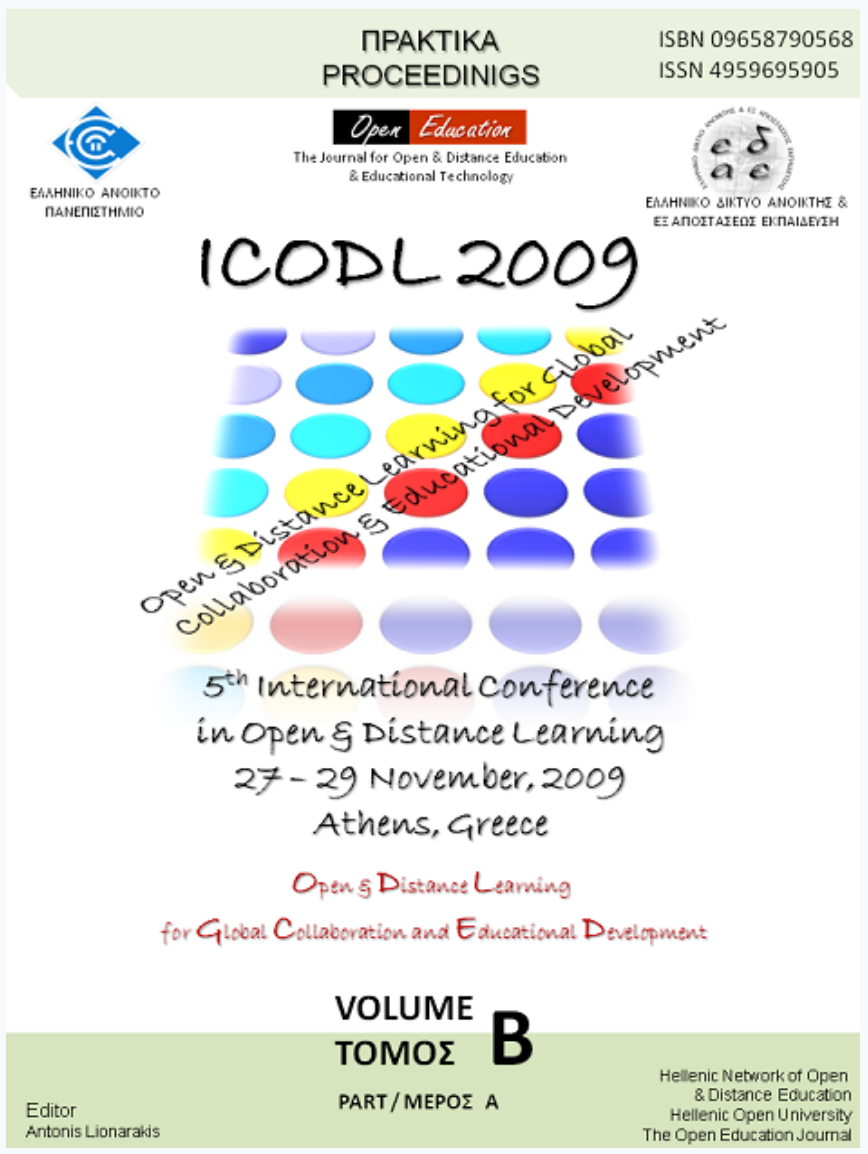

\section{Making the best of what we have: Lifelong distance e-learning revitalizing small remote schools}

Thanasis HADZILACOS, Nicos SIFAKIS, Demetra EGARCHOY, Maria FOUNTANA

doi: $10.12681 /$ icodl.466 


\title{
"Making the best of what we have: Lifelong distance e-learning revitalizing small remote schools"
}

\author{
Thanasis HADZILACOS \\ Professor \\ Open University of Cyprus, \\ Thanasis.Hadzilacos@,ouc.ac.cy
}

\section{Demetra EGARCHOY}

Researcher,

Research Academic Computer Technology Institute

egarchou@cti.gr

\section{Nicos SIFAKIS}

Asst Professor, Hellenic Open University, Sifakis@eap.gr

\section{Maria FOUNTANA}

Researcher,

Research Academic Computer Technology Institute, fountana@cti.gr

\begin{abstract}
This paper presents the design and initial implementation of an ICT-based distance learning framework that exploits current trends in distance learning, in particular elearning tools and features that are collectively known as "Web 2.0 tools" (e.g., blogs, wikis, social networks, podcasting). The project involves people who live in remote areas and aims for the mutual interaction, creation, share and reuse of information in order to provide useful lifelong education towards shaping the local mentality of the remote community from that of an overlooked inhabitant of a forgotten region to a European citizen, at the same time respecting linguistic and cultural diversities.
\end{abstract}

\section{Introduction}

Recent years have seen great advances in the ways in which the Internet is used by more and more people as a means of communicating and learning. The rapid growth of connection speeds and the enormous capability of storing text and audiovisual materials have not only facilitated the exchange of ideas, it has also enabled social interaction and proved to be an invaluable instrument in empowering all aspects of teaching and learning. Recent studies show that the appropriate use of technology in education can play a vital role in the development of autonomous learners, while, at the same time, significantly improving and enriching the learners' command of learning skills (Hakkarainen, 2009). This is particularly significant when the learners involved are inhabitants of geographically "remote" areas who can really make the best of both local infrastructures (e.g., local schools, technological support) and ICTdriven assistance (provided on-site and at a distance) as a means of meeting their ongoing professional and educational demands.

Historically, "center" and "remote" refers to human activity: productive, commercial, cultural, educational, while these roles change throughout history. For example, 
places by the sea used to be "central" and places in the mountains "remote", but at specific times these roles reverse. Whatever it may mean, "remote" has an effect: some of the dynamic elements of the society leave it to go to more "central" places. Thus today, "remote" places, usually situated a long distance from metropolitan centres ("central" places), are inhabited by few people, most commonly older than younger, who mainly practice "traditional professions" such as agriculture, fishery and in some cases tourism.

In this paper, we explore a distance learning (DL) framework that takes advantage of existing infrastructures and 'revitalizes' small, "remote" schools in an attempt to upgrade their already significant role in the local communities by making inroads to new educational opportunities and thus eliminate the abovementioned "remote" effects. The DL framework employed builds on previous experience (e.g.,

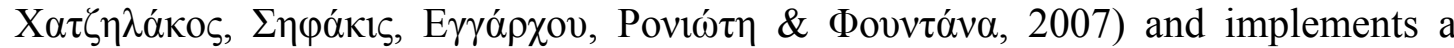
knowhow that merges pedagogically informed DL methodology with cutting edge technology.

\section{Project background}

The REVIT project ('REVIT: Revitalizing Small Remote Schools for LifeLong Distance e-Learning', http://revit.cti.gr) is co-funded by the European Union (Lifelong Learning Programme / Transversal Programme / Key Activity 3: ICT European Commission, EACEA) and has a duration of two years, from 01.01.2009 to 31.12.2010. The key goal of the project is to examine through a scalable example, whether it is possible and economically feasible in actual practice to substantially supplement the meager and sometimes irrelevant educational opportunities normally available to residents of remote and insular regions in the $\mathbf{E} \mathbf{U}$ through modern ICT-based distance education, utilizing existing infrastructure at otherwise declining schools and revitalizing their operation in order to become multi-purpose local learning centres accessible to all.

The REVIT project addresses children and adults, professionals or otherwise, who are either interested in complementing the mainstream education currently offered, or in receiving further training in their professional domain or even simply becoming familiar with the use of ICT in their everyday life. For this purpose, we have begun to design and implement a series of e-courses that are grounded in remote participants' actual needs, collected in Cyclades (Greece), Fornetka (Poland), Kula (Bulgaria) and Palaichori (Cyprus). To achieve these goals, modern synchronous and asynchronous tools are being used, based on Web 2.0 technology.

Partners of the REVIT project, with the Research Academic Computer Technology Institute (CTI) acting as the coordinating Institution, are: Kokkola University Consortium Chydenius (Finland), CODN (Poland), Zinev Art Technologies (Bulgaria), Open University of Cyprus (Cyprus), CINECA (Italy), Directorate of secondary education of Cyclades (Greece), Veikko Vionoja Primary School (Finland), Public Primary School in Fornetka (Poland), Kula Municipality (Bulgaria), 
Community of Palaichori (Cyprus), Biocert (Italy) and represent University departments, Teacher Training centres, Research Institutes and small, remote municipalities.

\section{Methodology}

The guiding principle behind REVIT stems from the observation that European citizens living in remote rural or insular areas are often excluded from mainstream educational activities easily accessible by people living in larger cities. Fewer opportunities are available to both young pupils and adults for lifelong learning opportunities. The project aims to design and implement an ICT-based distance learning framework incorporating and exploiting new trends in distance learning, especially eLearning 2.0 tools and features (e.g. blogs, wikis, social networks, podcasting) brought by Web 2.0 developments in the domain of ICT (Collis \& Moonen, 2008; O'Reilly, 2007). Our aim in this project is to use these tools in ways that promote mutual interaction among participants and empower them in creating, sharing and reusing ideas and information, thereby providing useful lifelong education that is aimed at shaping the local mentality of the remote community from that of an overlooked inhabitant of a forgotten region to an actively participating European citizen.

To achieve these goals, the project intends to focus on engaging the local schools, which usually play a central role in the community activities of these areas, while, in the more unfortunate remote areas, we will be using schools that have been active in providing formal education for the children of the local communities, and face the risk of closing due to lack of pupils. In this way, we wish to 'REVITalize' the schools and provide incentives to upgrade their role in the local community by playing an active part in catering for adult learning. To that end, the project intends to use the school premises, their existing ICT infrastructure, their human resources and, most importantly, the respect they command in the local community. In addition, the project will produce a comprehensive open learner-driven ICT-based distance learning framework including methodologies for (a) enabling members of remote rural communities to identify their learning needs, (b) enabling educators to design, create and deliver apt educational material, (c) a web-based DL service that provides tools for setting up and managing courses, for accessing, retrieving, creating, storing educational content, social tools for interacting with and establishing online communities with common educational concerns at national and European levels, and (d) a set of tested model e-courses available for other interested communities.

The proposed Distance Learning Scheme allows target groups to:

- Participate via video conferencing in a lesson delivered by a remote instructor, being able to interact through specific ICT tools, either with the instructor or with other learners (synchronous mode of distance learning)

○ Attend pre-recorded lessons as delivered by a remote instructor through a specific tool 
○ Work on their own using appropriate educational material and software on the school's computers (asynchronous mode of distance learning) and

o Communicate, cooperate and create using the modern tools and communication spaces available, through well designed and structured educational activities, with their peers in other participating countries.

Web 2.0 tools are integrated in ways that actively engage participants by viewing them as co-developers of the e-course's content and structure (following Cole, 2008), thereby harnessing the collective experience (Wenger, 2006) and providing richer learning experiences for all involved (Solomon \& Schrum, 2007).

\section{Current developments}

As already mentioned, we have identified the educational needs of the "pilot" application areas and initialized the design and implementation of a number of DL schemes and e-courses that have either started to run or are programmed to run in the next few months. In what follows, we will shortly present the tasks currently accomplished.

\section{- Identification of Educational needs in "remote" areas}

Since the REVIT e-courses draw on specific needs of the remote areas, a methodology for detecting educational needs was developed in order for all partner countries to conduct their needs analysis based on a common ground but also in order for guidelines to be available for future needs analysis. The needs analysis methodology (Andreou, Hadzilacos, Kyriakou, Liasis, Mavroudi, Egarchou, Fountana \& Zagouras, 2009) includes:

O investigation of the technical infrastructure of the remote areas (e.g. availability of Internet Connection, availability of PCs etc);

$\circ$ visits in the application areas and interviewing techniques (e.g. small group or public discussions, brainstorming, use of questionnaires etc);

$\circ$ encouragement of interviewees to express their actual needs (e.g. the topics should address mostly real educational needs like "tourism-focused English course" rather than just something that "would be nice to know" like "building web sites");

$\circ$ receiving commitment of participation (i.e. making explicit the duration of the courses and the methodological approach to be used, the roles of the people involved in the courses as well as their obligations and duties).

The "pilot" remote areas for our venture are: Cyclades islands in Greece, Ullava in Finland, Fornetka in Poland, Kula in Bulgaria and Palaichori in Cyprus. Needs analysis in these areas that took place following this methodology promoted the following list of desirable courses:

\begin{tabular}{|c|c|c|}
\hline REVIT: Suggested List Of Courses & \\
\hline $\begin{array}{c}\text { Implementation } \\
\text { Country }\end{array}$ & List of Subjects & $\begin{array}{c}\text { Comon and/or Popular } \\
\text { Courses }\end{array}$ \\
\hline
\end{tabular}




\begin{tabular}{|c|c|c|}
\hline Greece & 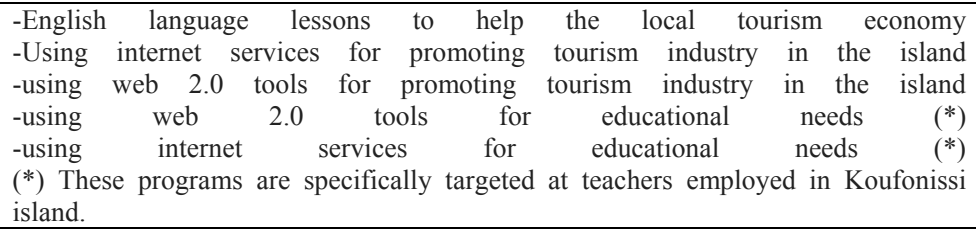 & $\begin{array}{l}\text { 1. English language lessons } \\
\text { (for tourism) } \\
\text { 2. EFL for Teachers, for } \\
\text { students } \\
\text { 3. Using web } 2.0 \text { tools / } \\
\text { Internet Services for tourism } \\
\text { 4. Using web } 2.0 \text { tools । }\end{array}$ \\
\hline Finland & $\begin{array}{l}\text { - course about the use of ICT } \\
\text { - language course (english or spanish) } \\
\text { - handicrafts } \\
\text { - entrepreneurship-course } \\
\text { - special needs in education } \\
\end{array}$ & $\begin{array}{l}\text { Internet Services for } \\
\text { education } \\
\text { 5. Agrotourism } \\
\text { 6. Organic farming } \\
\text { 7. Marketing }\end{array}$ \\
\hline Cyprus & $\begin{array}{l}\text { - Introduction to ICT (use of the tools) } \\
\text { - Agrotourism } \\
\text { - E-marketing (including setting up an e-shop to sell their local products) } \\
\text { - Caring for the elderly } \\
\text { It's likely that there will also be interest for the following subjects: } \\
\text { - Organic farming } \\
\text { - Old house repairs }\end{array}$ & $\begin{array}{l}\text { and Courses suggested by a } \\
\text { single partner: } \\
\text { 8. Handicrafts }\end{array}$ \\
\hline Bulgaria & $\begin{array}{l}\text { - Agrotourism } \\
\text { - Organic agriculture } \\
\text { - Internet marketing of local products } \\
\text { - Computer and Internet skills }\end{array}$ & $\begin{array}{l}\text { 10. Old house repairs family } \\
\text { 11. Successful } \\
\text { functioning }\end{array}$ \\
\hline Poland & $\begin{array}{l}\text { - using computer and the Internet (all) } \\
\text { - science, ICT, EFL (school education) } \\
\text { - Successful family functioning (family communication, raising a non-violent child, } \\
\text { supporting children in their development) } \\
\text { - Agrotourism } \\
\text { - Ecology Course - Recycling }\end{array}$ & $\begin{array}{l}\text { 12. Science for students } \\
\text { 13. Special needs in education } \\
\text { 14. Ecology Course - Recycling }\end{array}$ \\
\hline
\end{tabular}

Table 1: REVIT suggested list of courses as emerged through "needs analysis" in application areas

\section{- Design of the model and specifications for the REVIT e-courses}

We have developed the details of the distance learning model which is common for both school and adult education. It is actually reflected in the REVIT e-course definition and specifications. A REVIT e-course is a structured set of learning activities (including their sequencing), which have to be oriented towards the needs of learners and are aimed at a set of (knowledge, aptitude and attitude) learning objectives (Andreou, Hadzilacos, Kyriakou, Liasis, Mavroudi, Egarchou, Fountana \& Zagouras, 2009):

○ for a specific learner profile,

○ utilizing advanced multimedia interactive learning objects,

o with a learner-centric blended distance learning methodology,

○ using Web 2.0 tools, and synchronous/asynchronous e-learning environment.

\section{A REVIT e-course includes:}

$\bigcirc$ the set of learning activities (what the learner does e.g. Make a list of adjectives from Act I Scene II from Shakespeare's Hamlet);

$\bigcirc$ the sequencing graph of these learning activities;

o the learning objects involved (in an appropriate repository e.g. the text of Shakespeare's Hamlet, a video lecture, a set of multiple choice questions);

$\circ$ the learning objectives (overall and per learning activity);

o relevant metadata;

○ the learning methodology, which includes:

a. Pedagogical considerations, 
b. learning environment (along with technical infrastructure needed),

c. use of Web 2.0 tools,

d. student-student and student-teacher interaction

e. time requirements,

f. tutor profile

○ learner profile including prerequisites.

- Sample REVIT e-courses

In what follows, we present two examples of REVIT e-courses.

\section{Web 2.0 tools for EFL Teacher Training}

In the past few years, web 2.0 tools have been frequently implemented in DL-oriented teacher training seminars and foreign language learning courses (e.g., Deutschmann, Panichi \& Molka-Danielsen, 2009; Lamy \& Hampel, 2007; Karpati, 2009). For the purposes of this project, we have developed and implemented a series of teacher training seminars that engage EFL teachers on the subject of lesson planning [1]. Teachers from Poland, Cyprus, Bulgaria, Italy and Greece participated in a biweekly seminar and were invited to implement specific Web 2.0 tools while carrying out the following activities:

- Podcasts: used as a repository of trainees' audio recordings of actual lessons;

○ Wikis: used as a basis for collaboratively establishing "successful" lesson plans that meet different needs;

○ Blogs: trainees write their reflections on specific activities; blogs act as homework assigned and can serve for purposes of assessment;

○ REVIT forum: used by trainees for reading academic articles, exchanging messages, carrying out collaborative projects, etc.

The above activities are further supported by regular online meetings of all participants in which ideas are explored and the design of the e-course is further elaborated. In the next phases of this seminar, we intend to explore in more detail concerns that have to do with specific issues that arise in EFL teaching, such as classroom interaction, teaching oral skills to learners, learning how to implement alternative assessment tools with learners, selecting and adapting existing courseware, or developing/improving classroom management skills.

\section{Introductory course in using Web technologies}

This course aims at introducing all trainees to the use of web technologies through providing them with specific knowledge, skills and attitudes concerning the utilization of the internet, at the same time familiarizing them with the REVIT distance learning 
system and web tools, in order to be able to participate in the thematic REVIT ecourses of their interest.

More specifically, its main objectives include:

○ Knowledge of Terminology (e.g. Internet, Web, Upload/Download, tool, search machine, bookmark, browser) and Concepts (e.g. Hyperdocument, Information source, information validity, asynchronous communication, synchronous communication).

o Skills like:

- Use of the INTERNET and the WEB for obtaining content, searching for concrete information, communication, publishing, playing/idle, as alternative means of everyday activities and for transactions.

- Active use of terminology and ability to think with concepts (in Knowledge, above).

- Attitudes like:

- When confronted with a question or a task they should (a) consider and (b) use Web resources as information source, communication medium and (trans)action tool.

- To be comfortable with the use of the tools that they will use in the following courses.

The introductory course consists of 8 sections, i.e. groups of learning activities, in order to cover various interests and backgrounds of potential learners. Each section concerns a specific action that a learner could be interested in undertaking through the web. These sections along with some examples of learning activities are listed below:

1. Obtain content from the web (e.g. read an article; visit a URL; look at an image; listen to a song; watch a video; download a song, an image, a video; find provocative content).

2. Look up (search for) specific information (e.g. find a recipe; find a song's lyrics or a poem; compare prices for something I intend to buy; find out the score of yesterday's football match; enquire localized weather reports; search for a friend's name in Facebook; find travel info; use on online encyclopedia; translate a text/website/email).

3. Communication (e.g. send an email; online Chat; send a file; make a video call; discuss in a forum; add a friend in Facebook).

4. Create/Publish content (e.g. upload a picture in Facebook; contribute to a blog; upload a video on YouTube; create a new page).

5. Play/Idle (e.g. Google earth; play a game online; participate in a contest; vote/rate).

6. Alternative way for everyday activities (e.g. read the news; follow a course; listen to a radio station; watch a movie online; prepare a dinner; see the weather forecast).

7. Transactions \& Services (e.g. book a trip ideas for activities; purchase books, CDs, clothing, etc; book a seat for the theatre; buy a song for your iPod).

8. Authorized access (e.g. create an account; sign in/sign out). 
This REVIT e-course is being designed and developed in English by a workgroup of ICT teachers and developers from Research Academic Computer Technology Institute (RA.CTI) and Open University of Cyprus (OUC)[2], according to the specifications for the REVIT e-courses as implemented in the framework of the project. This e-course will be later localized to the various languages of the project partner consortium.

\section{Conclusion}

We have presented the design and initial implementation of a European project that aims at revitalizing small and geographically remote schools by utilizing their premises, existing ICT infrastructure and human resources in order to approach local people and provide them with access to distance learning schemes, introducing them into well-structured ICT-enhanced educational activities and material in thematic areas of their interest (e.g., agriculture, everyday life, cookery, foreign language learning, computer and internet basic skills acquisition).

\section{Notes}

[1] The course described here was developed by Nicos Sifakis. Further stages of the course will be codesigned by Nicos Sifakis and Sophie Ioannou-Georgiou.

[2] Members of the development workgroup for the Introductory Course: Christos Christakoudis, Dimitris Athanasopoulos, Spyros Papadakis, Yiannis Katsenos (RA.CTI) and Panayiotis Kyriakou, Anna Mavroudi, Maria Andreou, Grigoris Liasis (OUC)

\section{References}

Andreou, M., Hadzilacos, Th., Kyriakou, P., Liasis, G., Mavroudi,A., Egarchou, D., Fountana, M., Zagouras, G. (2009). D2.3 "Guidelines for Using the DL Framework for Adult Education (Continuous Education)", REVIT Project Deliverable.

Cole, M. (2008). 'Using Wiki technology to support student engagement: lessons from the trenches'. Computers \& Education, 52/1: 141-146.

Collis, B. \& Moonen, J. (2008). 'Web 2.0 tools and processes in higher education: quality perspectives'. Educational Media International, 45/2: 93-106.

Deutschmann, M., Panichi, L. \& Molka-Danielsen, J. (2009). 'Designing oral participation in Second Life - a comparative study of two language proficiency courses'. ReCALL, 21/2, 206-226

Hakkarainen, K. (2009). 'Three generations of technology-enhanced learning'. British Journal of Educational Technology, 40/5: 879-888.

Karpati, A. (2009). 'Web 2 technologies for Net Native language learners: a "social CALL", . $\operatorname{ReCALL}, 21 / 2$ : 139-156.

Lamy, M.-N., \& Hampel, R. (2007). Online Communication in Language Learning and Teaching. New York: Palgrave Macmillan.

O'Reilly, T. (2007). 'What is Web 2.0: Design Patterns and Business Models for the Next Generation of Software'. Communications \& Strategies, 65: 17-37. Available at SSRN: http://ssrn.com/abstract=1008839 $($ accessed 27-09-2009) 
$5^{\text {th }}$ International Conference in Open \& Distance Learning - November 2009, Athens, Greece - PROCEEDINGS

Solomon, G. \& Schrum, L. (2007). Web 2.0: new tools, new schools. Washington, DC: International Society for Technology in Education.

Wenger, E. (2006) Communities of practice - Learning, Meaning and Identity. Cambridge: Cambridge University Press.

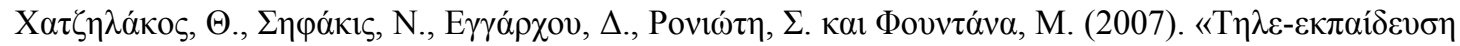

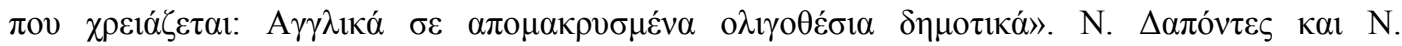

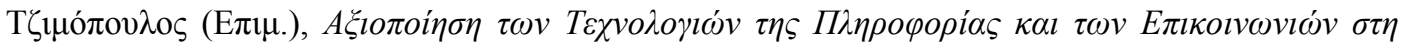

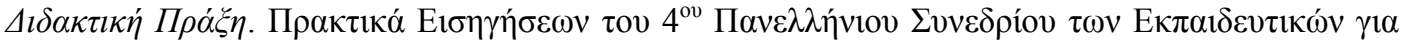
$\tau \Vdash \varsigma$ TПЕ, Тó $\mu \circ \varsigma \Gamma, \sigma \varepsilon \lambda . ~ 25-34$. 